\title{
Assessment of Water Quality Index in the St. Thomas Mount Block Using GIS and Remote Sensing
}

\author{
Shanmugam Jayalakshmi*, Esakimuthu Velappan \\ Institute of Remote Sensing, Anna University, Chennai 600 025, India \\ Received: 29 January 2015 \\ Accepted: 15 March 2015
}

\begin{abstract}
Groundwater is an essential natural resource for securing drinking water and plays a significant role in human wellbeing. However, in recent times the pressure on groundwater has increased both quantitatively and qualitatively. The drinking water sources are threatened by contamination through human exploitation. The objective of this study is to assess and map the spatial distribution of groundwater quality in the St. Thomas Mount Block of Kancheepuram District, Tamilnadu, using geographical information systems (GIS) and remote sensing (RS). This block has been experiencing rapid industrialization and urbanization, and this has made people in the area depend on groundwater resources. The suitability of water for drinking purposes in the study area is calculated using water quality index (WQI), considering land use changes. WQI is calculated by using standards of drinking water quality recommended by the Bureau of Indian Standards 10500:1993 (BIS) and the Indian Council for Medical Research (ICMR). In the present study, nine water-quality parameters were considered for computing WQI. The inverse distance-weighted (IDW) spatial interpolation technique was used to estimate the spatial distribution of groundwater parameters and WQI. It was observed from the WQI map that around $76.5 \%$ of the total area is unfit for drinking.
\end{abstract}

Keywords: water quality index, GIS, land use and land cover, spatial distribution

\section{Introduction}

Water is essential for life and plays a vital role in the Earth's ecosystem. It is one of the most critical, scarce, precious, and replenishable natural resource that cannot be created [1]. The utilizable water resources in India are estimated to be 1,123 BCM, out of which $690 \mathrm{BCM}$ are surface water resources and $433 \mathrm{BCM}$ are groundwater resources [2]. Groundwater serves as the main source of water in urban areas. It is used for drinking, industrial, and domestic purposes, and is often over exploited. Due to the rapid growth of industries, the disposal of liquid and solid wastes is increasing, thereby polluting soil and groundwater. If the

*e-mail: j_lak2001@yahoo.co.in waste is not disposed of properly, then it percolates into the ground and causes problems like groundwater contamination, degradation of vegetation, soil contamination and modification of soil properties, etc. Growing use of pesticides, fertilizer, and numerous point sources of contamination constitute a threat to the quality of groundwater. The quality of water is generally defined in terms of its physical, chemical, and biological parameters [3] and measured as water quality index (WQI) to assess whether or not water is potable. WQI is a single numeral that expresses the overall water quality at a certain location, based on several water quality parameters [4]. Hence, for any city, the groundwater quality map is a valuable parameter for evaluating potability and it is also an indication of potential environmental health problems [5]. 
Geographical information systems (GIS) and remote sensing (RS) have been used extensively to assess the water quality all over the world $[3,6,7]$. The advancement of GIS and spatial analysis helps us to integrate laboratory data with geographic data, and to model the spatial distributions of water quality parameters robustly and accurately.

The objective of this study is to assess and map groundwater quality in the St. Thomas Mount Block of Kancheepuram District, Tamilnadu, India, which is affected by the rapid growth of different kinds of industries, namely rubber, tannerries, chemicals, pharmatueticals, fertilizers, etc. In India, tanneries play a major role in economic development; however, its effluents are ranked as high pollutants among all other industrial wastes. India annually produces about 1.6 billion square feet of finished leather from ruminants alone. The earnings from export have been of the order of RS 6,000 crores annually [8]. There are over 3,000 operational tanneries in India and over $60 \%$ of them are in Tamilnadu. These tanneries generate effluents of about 1.5 billion litres per day containing several thousand PPM of organic and inorganic impurities. These effluents are disposed on land and water bodies without proper treatment.

\section{Study Area}

The study area is the St. Thomas Mount block (Fig. 1) which lies in the eastern part of the Kancheepuram district. The block is surrounded by Chennai city in the north, Kundrathur block in the west, and Tiruporur and Kattankulathur in the south. To the eastern side of the block is the Bay of Bengal. The study area is chiefly underlined by Charnockites of Archaean age and marine sediments of Quaternary age along the coastal tracts. The predominant landforms observed in the central and western parts of the block are buried pediments, shallow and deep, pediment and residual hills. Backwaters, beach, and coastal plains are found on the eastern part of the block adjoining the coastal areas. It includes agricultural areas, built-up areas, forest, wastelands, water bodies, and wetlands. The rainfall station considered for this block is located at Tambaram. A maximum average annual rainfall of $1,702.2 \mathrm{~mm}$ and a minimum average annual rainfall of $806.7 \mathrm{~mm}$ were recorded in 2005 and 2012, respectively. The groundwater table of the study area varies from 4 to $6 \mathrm{~m}$. The population of this block as per 2011 census is around 10 lakhs with total water demand of 135 lakhs liters.

\section{Methodology}

\section{Land Use and Land Cover Map}

Level 1 classification of the land use and land cover (LULC) map was done with the help of ERDAS 9.1 software using LISS III (2000) and LISS IV (2012) satellite imagery of resolutions 23.5 and $5.8 \mathrm{~m}$, respectively. Toposheet no $66 \mathrm{D} / 1,2$ and 5 was used to prepare the boundary map of the study area. To validate the LULC map, accuracy assessment - an important step in the process of analyzing RS data - was performed. Twelve sites were selected based on random sampling, and the ground truth verification was done for the same sites with the help of mobile GPS.

\section{Water Quality Index}

The WQI concept is based on the comparison of the water quality parameters with the regulatory standards, and provides a single numeral that expresses the overall water quality at a certain location based on several water quality parameters. WQI improves the understanding of water quality issues by integrating complex data and generating a score that describes the water quality status and evaluates the water quality trends. In the present study, the WQI was calculated using the standards of drinking water quality rec-

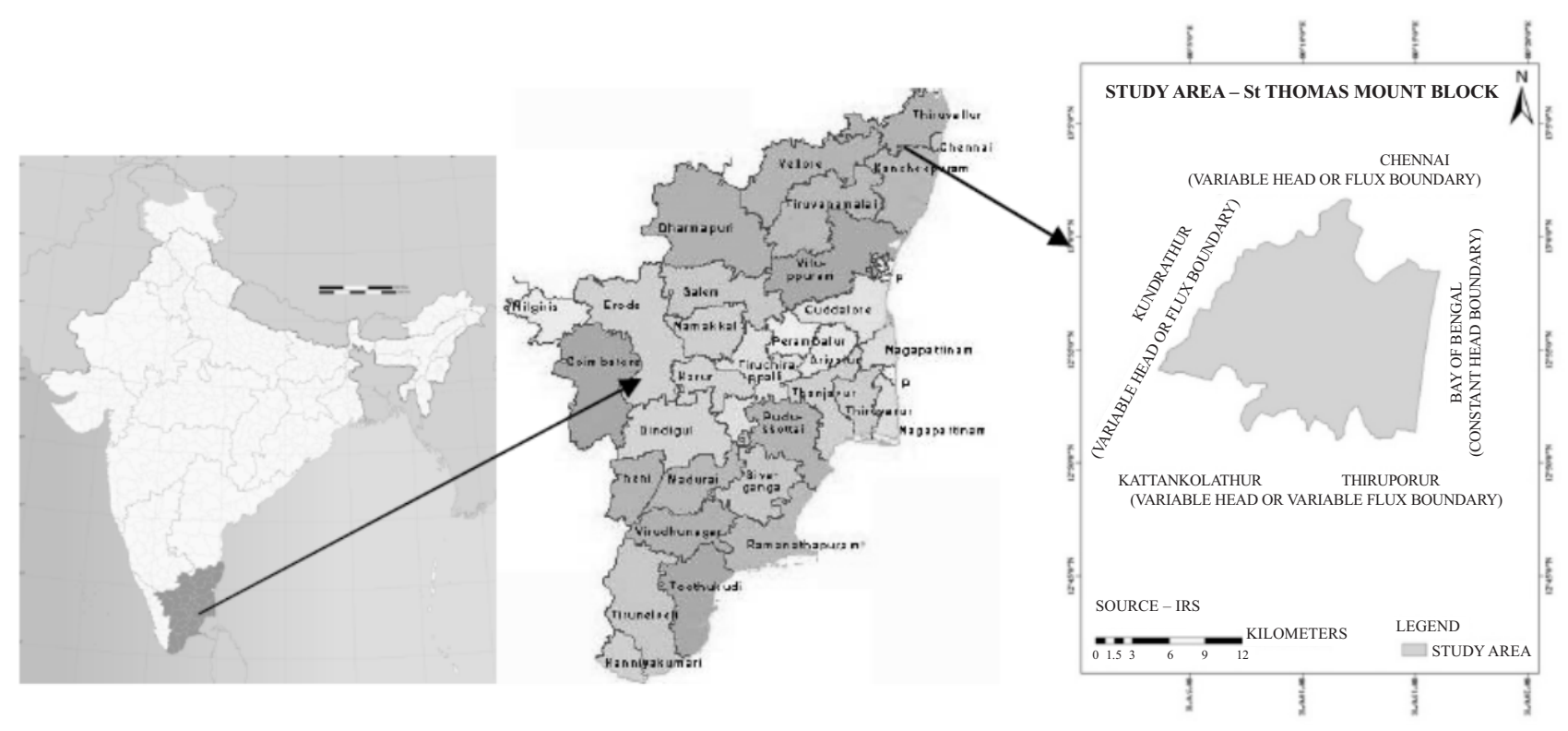

Fig. 1. Study area. 


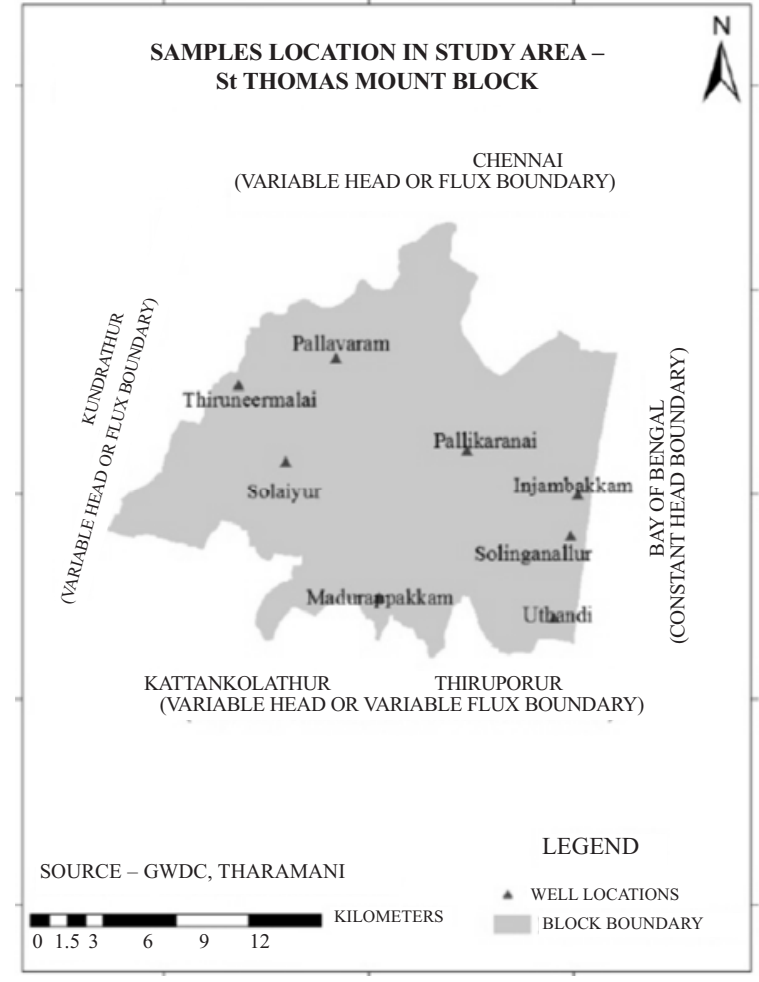

Fig. 2. Sampling wells.

ommended by the Bureau of Indian Standards 10500:1993 (BIS) and the Indian Council for Medical Research (ICMR). A weighted index method is developed to determine the suitability of groundwater for drinking purposes. Fig. 2 shows the location of sampling wells. In the present study, nine water-quality parameters such as $\mathrm{pH}$, electrical conductivity (EC), total dissolved solids (TDS), total hardness $(\mathrm{TH})$, calcium, magnesium, bicarbonate, chloride, and sulphate were considered for computing WQI using Eq. (1).

$$
\mathrm{WQI}=\text { Anti } \log \left[\sum W^{n} n=1 \log 10 q_{n}\right]
$$

...where $W$ is the weightage factor computed using Eq. (2).

$$
W_{n}=K / S_{n}
$$

...where $K$ is the proportionality constant derived from Eq. (3).

$$
K=\left[1 /\left(\sum^{n} n=11 / S_{n}\right)\right]
$$

...where $S_{n}$ and $S_{i}$ are the BIS/ICMR standards for water quality parameters.

Quality rating $(q)$ is calculated using

$$
q_{n i}=\left\{\left[\left(V_{\text {actual }}-V_{\text {ideal }}\right) /\left(V_{\text {standard }}-V_{\text {ideal }}\right)\right] \times 100\right\}(4)
$$

...where $q_{n i}$ is the quality rating of the $i^{\text {th }}$ parameter for a total of $n$ water quality parameters, $V_{\text {actual }}$ is the value of the water quality parameter obtained from laboratory analysis, $V_{\text {ideal }}$ is the value of the water quality parameter according to the BIS standards, $V_{\text {ideal }}$ for $\mathrm{pH}=7$ and for other parameters it is equal to zero, and $V_{\text {standard }}=\mathrm{BIS} / \mathrm{ICMR}$ standard of the water quality parameter.

\section{Results and Discussion}

\section{Land Use and land Cover Map}

Figs. 3 and 4 show the LULC map of the study area for 2000 and 2012, respectively. It is classified into six classes: agricultural area, built-up area, forest, wastelands, water bodies, and wetlands. The accuracy of the map was checked by selecting 12 sites using random sampling method. Out of the 12 randomly selected sites, 10 were accurately placed on the same co-ordinates as in the LULC map. This shows that the map has an accuracy of $83 \%$. From Table 1 it is observed that agricultural lands, wastelands, water bodies, and wetlands were converted into built-up areas, with the forest area remaining the same for both the years considered.

\section{Spatial Distribution of Water Quality Parameters}

\section{Electrical Conductivity}

The importance of Electrical Conductivity (EC) is due to its measure of cautions, which greatly affects the taste and thus has significant impact on the user acceptance of the water as potable $[9,10]$. It is an indirect measure of total dissolved salts. High conductivity may arise through natur-

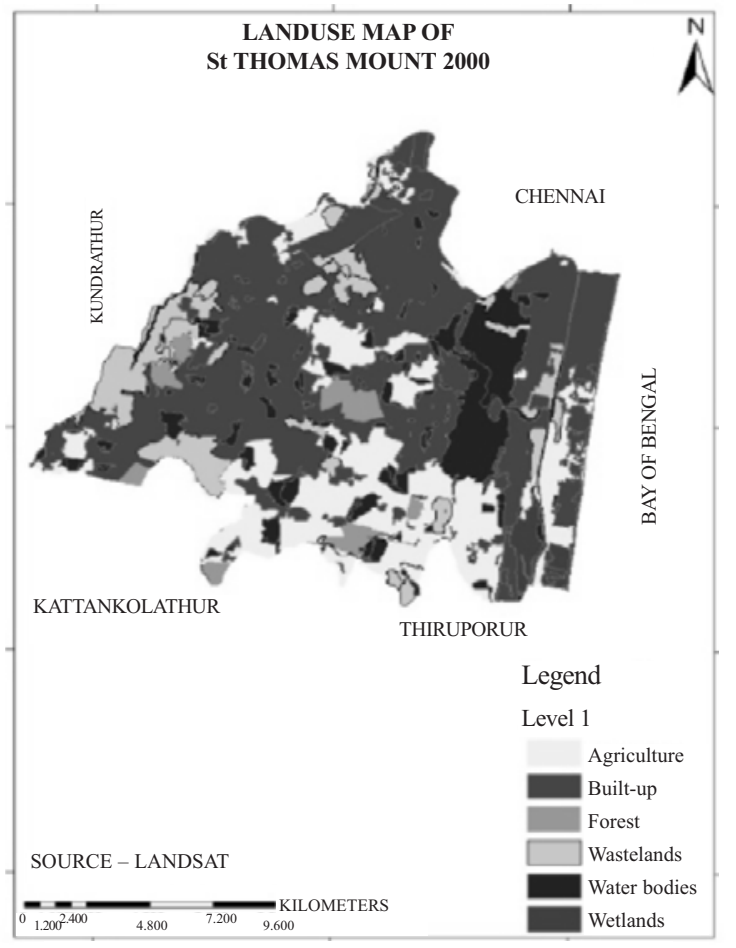

Fig. 3. Land use map for 2000. 
Table 1. Changes of LULC categories in 2000 and 2012.

\begin{tabular}{|c|c|c|c|c|}
\hline No. & Categories & $\begin{array}{c}\text { Area in } \\
2000(\%)\end{array}$ & $\begin{array}{c}\text { Area in } \\
2012(\%)\end{array}$ & $\begin{array}{c}\text { Change in } \\
\text { Area (\%) }\end{array}$ \\
\hline 1. & Agriculture & 21.533 & 14.522 & -7.011 \\
\hline 2. & Built-up & 48.633 & 64.560 & 15.927 \\
\hline 3. & Forest & 3.086 & 3.086 & 0.000 \\
\hline 4. & Wastelands & 10.395 & 6.750 & -3.645 \\
\hline 5. & Water bodies & 14.526 & 10.452 & -4.073 \\
\hline 6. & Wetlands & 1.827 & 0.629 & -1.198 \\
\hline & Total & 100.000 & 100.000 & 0.000 \\
\hline
\end{tabular}

al weathering of certain sedimentary rocks or may have an anthropogenic source, e.g. industrial and sewage effluent [9]. Fig. 5(a) shows the spatial distribution of EC in the study area. It is observed that the EC varies from 400 to $2,820 \mathrm{mg} / \mathrm{l}$, with a higher concentration of $2,820 \mathrm{mg} / \mathrm{l}$ observed in Madurapakkam, whereas a lower concentration of $400 \mathrm{mg} / \mathrm{l}$ was observed in Injambakkam and Selaiyur. EC is the capacity of electric current that passes through water. It is directly related to the concentration of ionized substances in water and is also related to hardness. According to Table 1 data, the built-up area increased around $16 \%$ from 2000 to 2012 . Electrical conductivity is the manifestation of the dissolved salts and is an indicator of water pollution, which has been found to be pretty high in the present study, indicating a high degree of water pollution due to effluent discharge [11].

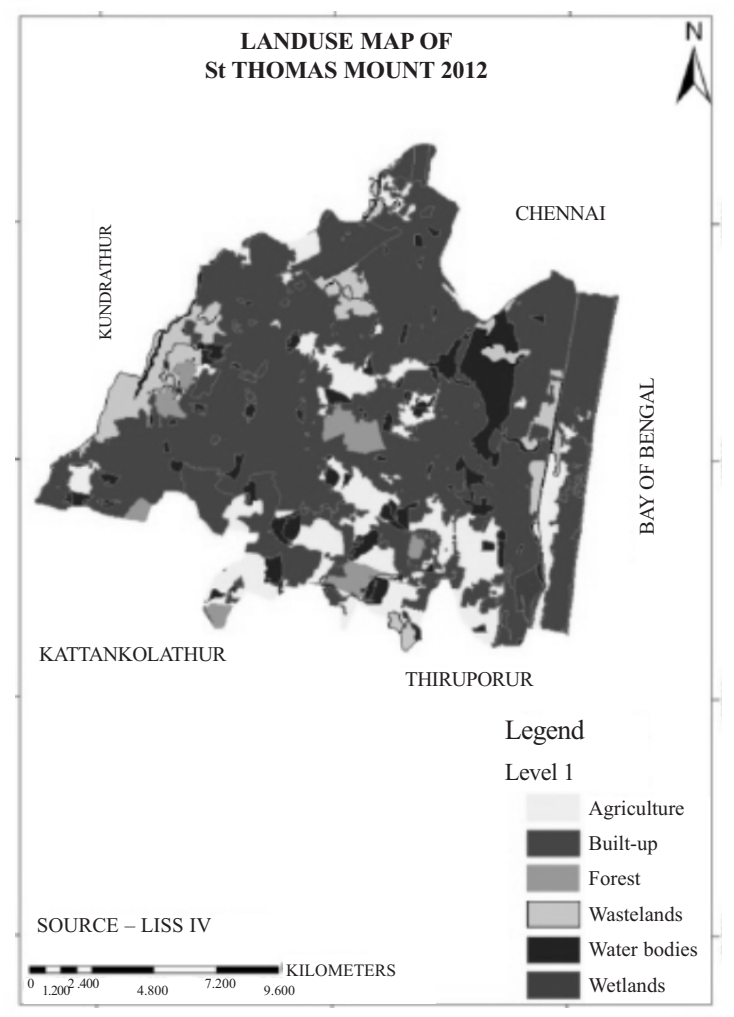

Fig. 4. Land use map for 2012.

\section{Calcium}

Calcium is a major constituent of various types of rock. Calcium is a cause for hardness in water and encrustation of boilers. Calcium is an essential constituent of human beings. The low content of calcium in drinking water may cause rickets and defective teeth. It is essential for the nervous system, cardiac function, and the coagulation of blood [12]. Spatial distribution of calcium is shown in Fig. 5(b). The concentration of calcium in the groundwater ranges from 12 to $100 \mathrm{mg} / \mathrm{l}$. Due to weathering action and organic matter degradation, a higher concentration of calcium (100 $\mathrm{mg} / \mathrm{l})$ was observed in Pallavaram, whereas a lower concentration of calcium (12 $\mathrm{mg} / \mathrm{l})$ was observed in Pallikaranai and Sholinganallur.

\section{Magnesium}

Magnesium is the fourth most abundant cation in the body and the second most abundant cation in intracellular fluid [13]. It is a cofactor for some 350 cellular enzymes, many of which are involved in energy metabolism. It is also involved in protein and nucleic acid synthesis and is needed for normal vascular tone and insulin sensitivity. Low magnesium levels are associated with endothelial dysfunction, increased vascular reactions, elevated circulating levels of C-reactive protein, and decreased insulin sensitivity. Low magnesium status has been implicated in hypertension, coronary heart disease, type 2 diabetes mellitus, and metabolic syndrome. Risk of magnesium toxicity is usually related to severe renal insufficiency (when the kidney loses the ability to remove excess magnesium) [14]. Spatial distribution of calcium is shown in Fig. 5(c). The concentration of calcium in the groundwater ranges from 23 to $225.96 \mathrm{mg} / \mathrm{l}$. Due to anthropogenic pollution, a higher concentration of magnesium (225.96 mg/l) was observed in Madurapakkam, whereas a lower concentration was observed in Injambakkam and Sholinganallur.

\section{Chloride}

Chloride in the form of $\left(\mathrm{Cl}^{-}\right)$ion is one of the major inorganic anions in water and wastewater. The salty taste produced by chloride concentrations is variable and dependent on the chemical composition of water [15]. Some water containing $250 \mathrm{mg} / \mathrm{L}$ may have a detectable salty taste if the cation is sodium. On the other hand, the typical salty taste may be absent in water containing as much as $1,000 \mathrm{mg} / \mathrm{L}$ when the predominant cations are calcium and magnesium [16]. A high chloride content may harm metallic pipes and structures, as well as growing plants [17]. Spatial distribution of chloride in the study area varies between 71 and $537 \mathrm{mg} / \mathrm{l}$ (Fig. 5 (d)). Due to mineral dissolution from industries, higher chloride concentration of $537 \mathrm{mg} / \mathrm{l}$ was observed in Madurapakkam, whereas a lower concentration of $71 \mathrm{mg} / \mathrm{l}$ was observed in Injambakkam and Sholinganallur. High chloride content in drinking water may lead to laxative effects. $p H$ 

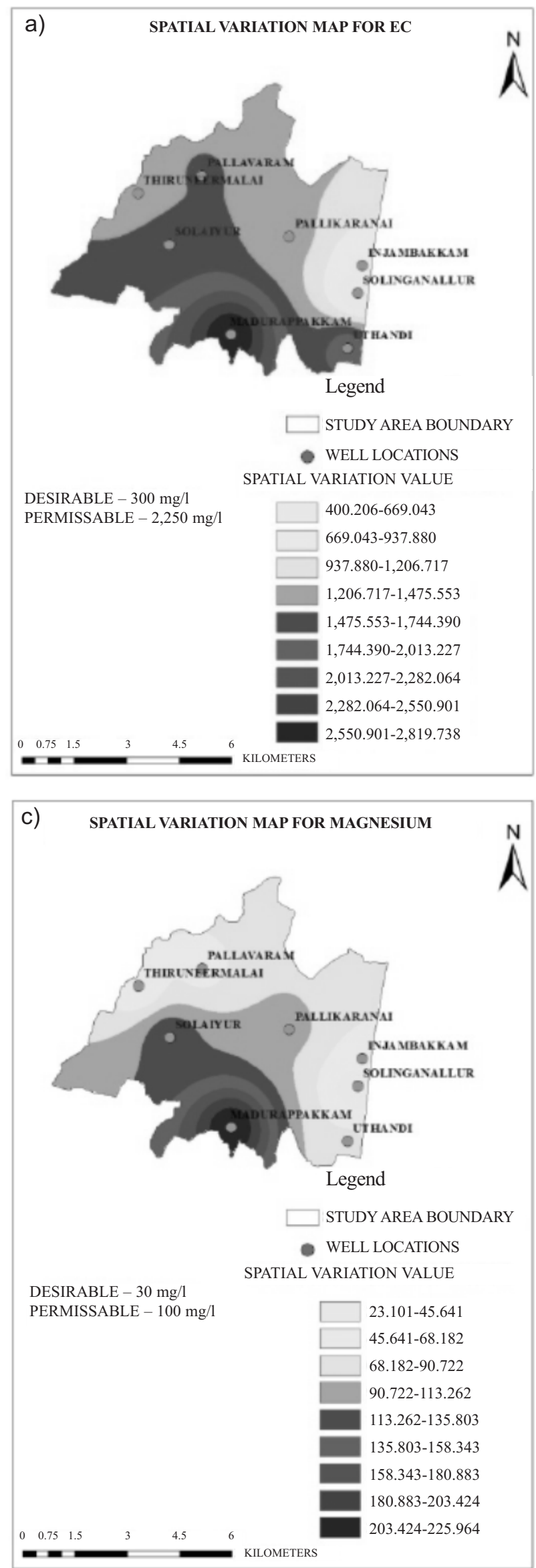
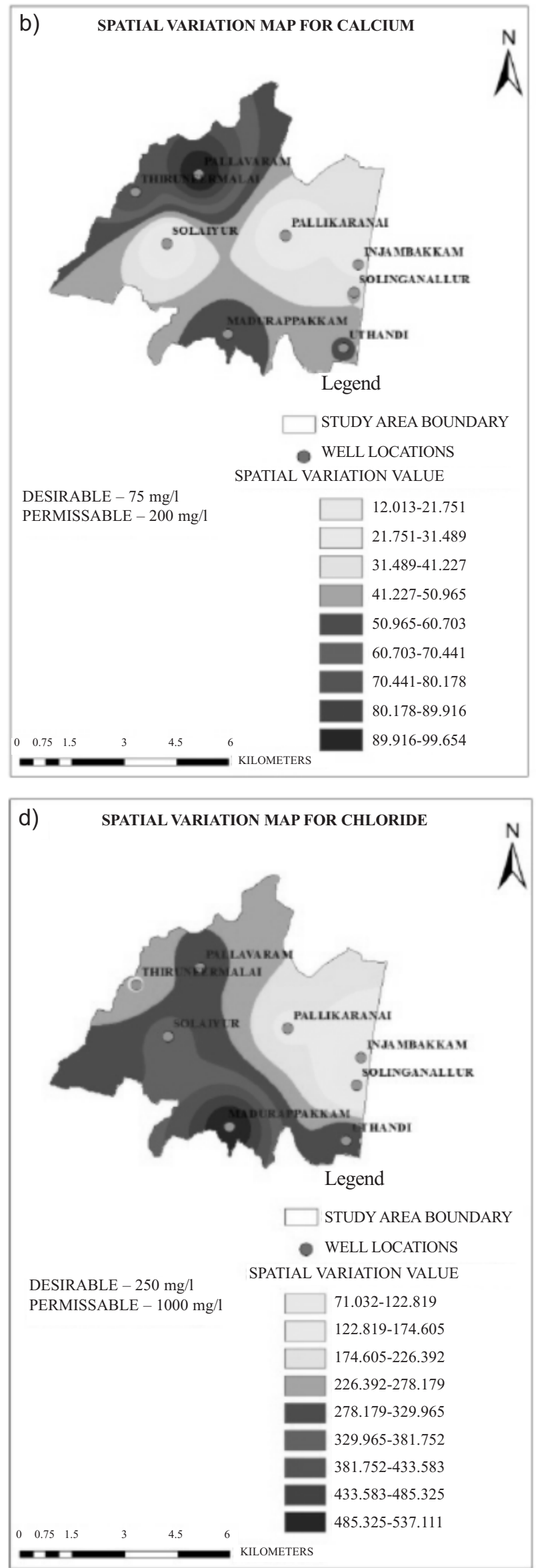

Fig. 5. Spatial distribution of water quality parameters: a) Electrical conductivity; b) Calcium; c) Magnesium; d) Chloride; e) pH; f) Total dissolved solids; g) Sulphate; h) Total hardness; i) Bicarbonate. 


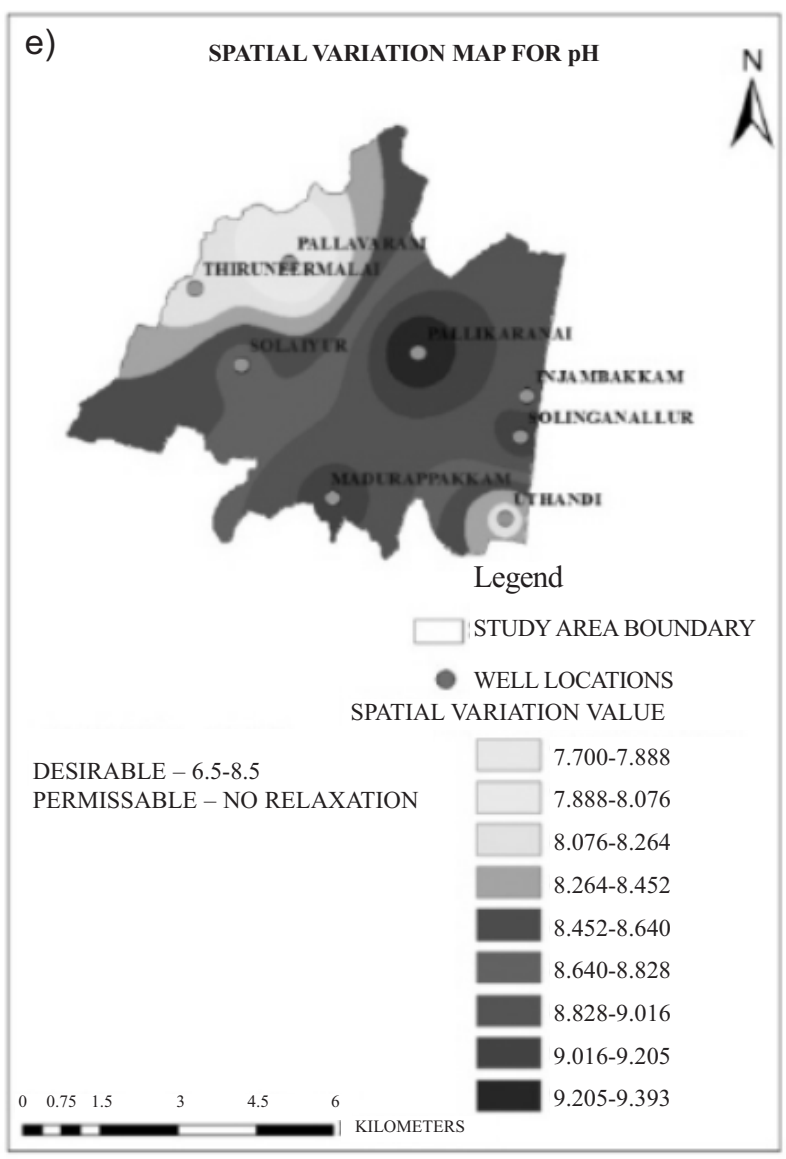

g)

SPATIAL VARIATION MAP FOR SULPHATE

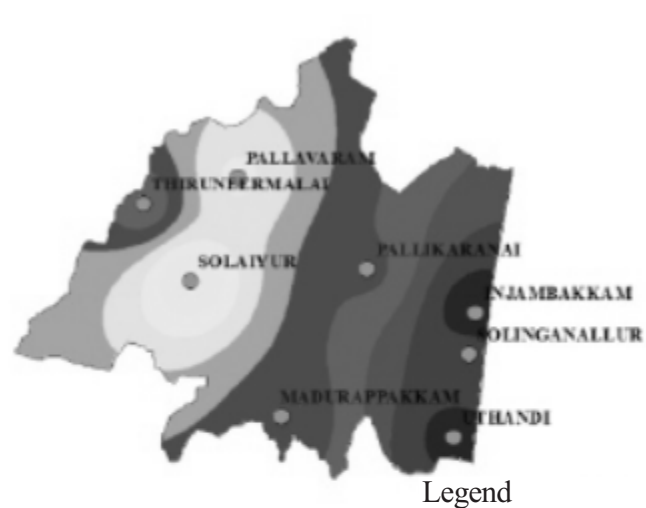

STUDY AREA BOUNDARY

WELL LOCATIONS

SPATIAL VARIATION VALUE

DESIRABLE - $200 \mathrm{mg} /$

ए 40.00920868-48.34141286

48.34141287-56.67361705

56.67361706-65.00582123

65.00582124-73.33802541

$73.33802542-81.67022959$

$81.6702296-90.00243378$

90.00243379-98.33463796

98.33463797-106.6668421

$106.6668422-114.9990463$

KILOMETERS

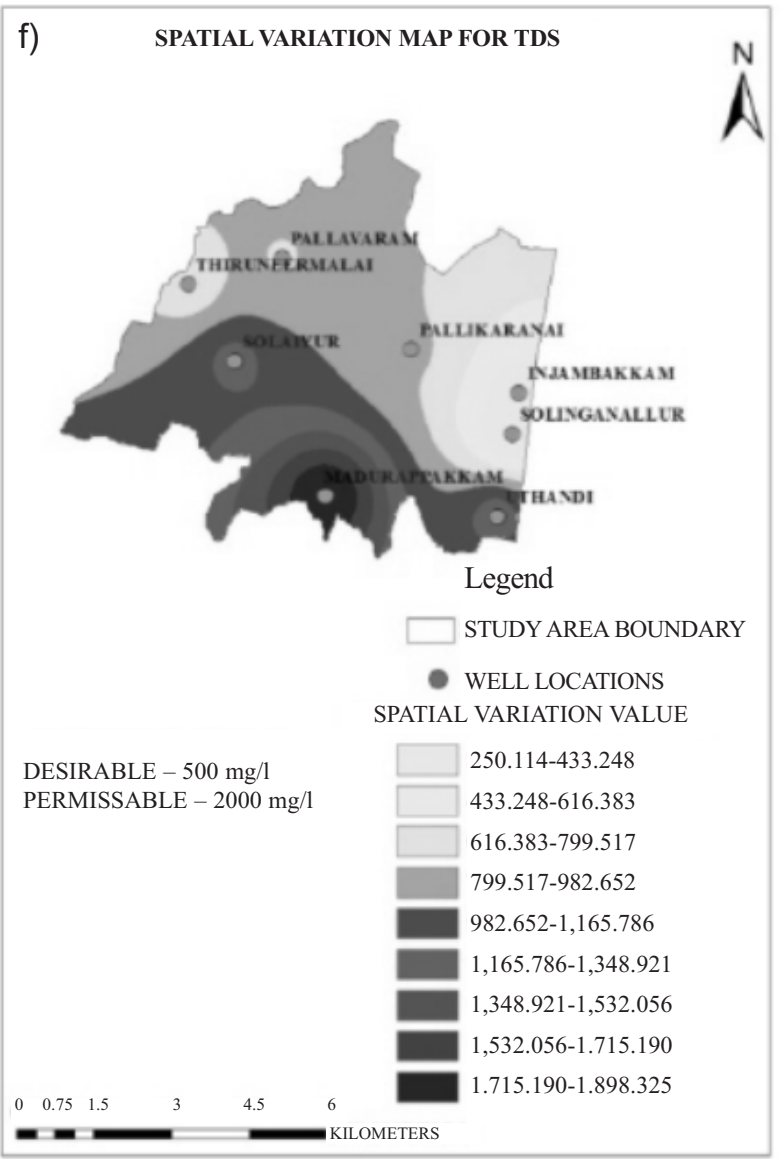

h)

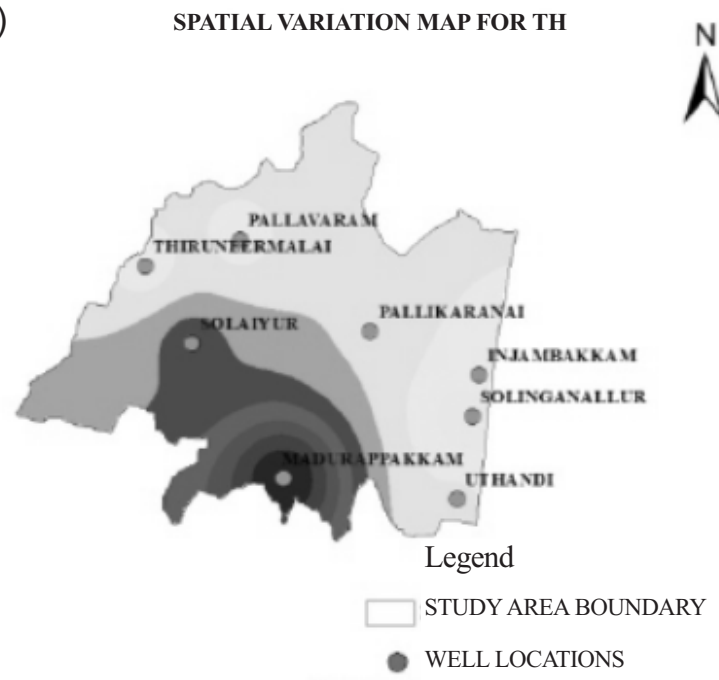

DESIRABLE - $300 \mathrm{mg} / \mathrm{l}$ PERMISSABLE - $600 \mathrm{mg} / 1$ SPATIAL VARIATION VALUE
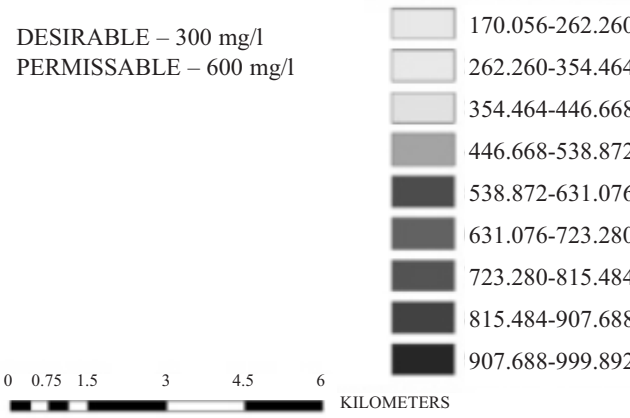

Fig. 5. Continued. 


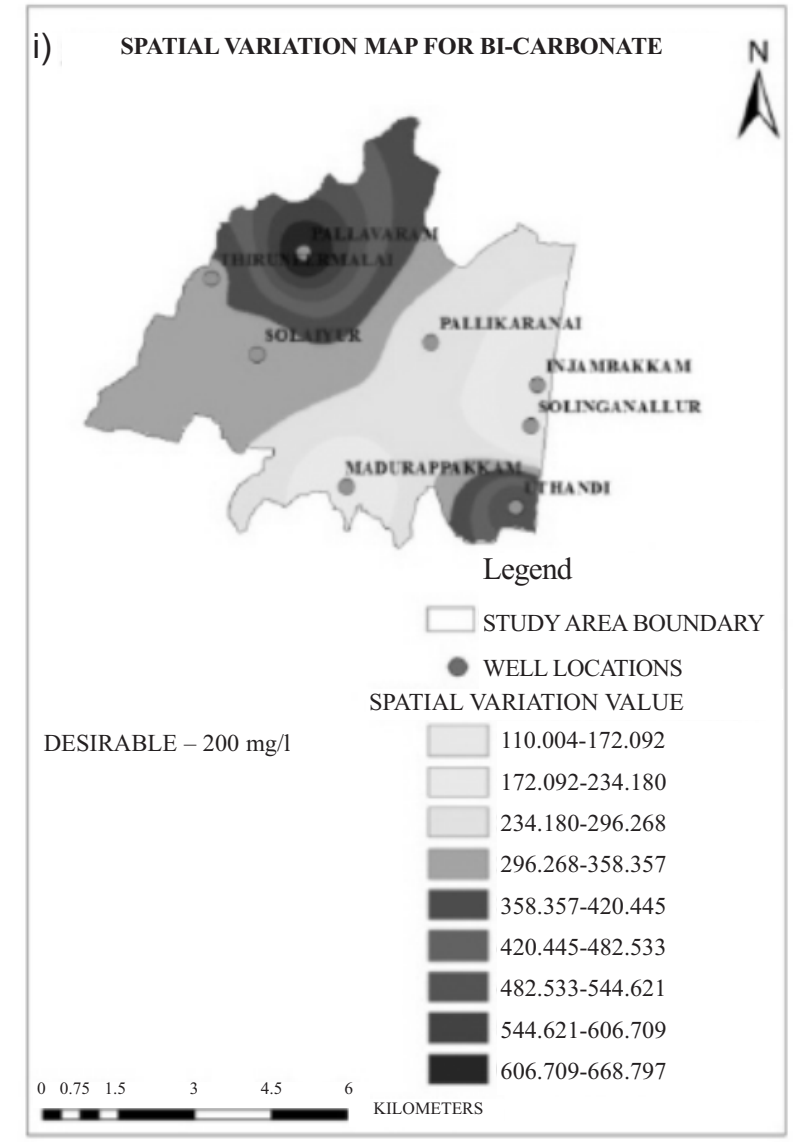

Fig. 5. Continued.

$\mathrm{pH}$, one of the most important and frequently used tests in water chemistry, ranged between 7.03 to 8.16 , which were within the IS and WHO acceptable limits (7.03-8.16). Practically every phase of water supply and wastewater treatment, e.g., acid-base neutralization, water softening, precipitation, coagulation, disinfection, and corrosion control, is $\mathrm{pH}$ dependent $[18,19]$. In the study area considered, $\mathrm{pH}$ level of water varies from 7.7 to 9.4 and is not in the desirable limit, which is 6.5-8.5 as specified by the BIS/ICMR standards. Fig. 5(e) shows higher $\mathrm{pH}$ concentration of 9.4 in Pallavaram due to the mixing of saline and fresh groundwater and mineral precipitation, whereas a lower concentration of 7.7 was observed in Uthandi.

\section{Total Dissolved Solids}

The spatial distribution of TDS ranges between 250 and $1,898 \mathrm{mg} / \mathrm{l}$. According to BIS and ICMR, the desirable limit of TDS is $500 \mathrm{mg} / \mathrm{l}$. Fig. 5(f) shows that in most of the places in the study area the TDS exceeds the desirable limit. If the TDS value is more than $500 \mathrm{mg} / \mathrm{l}$, it may cause gastrointestinal irritation. Due to mineral dissolution, a higher TDS concentration of $1,898 \mathrm{mg} / \mathrm{l}$ was observed in Madurapakkam, whereas a lower concentration of $250 \mathrm{mg} / 1$ was observed in Injambakkam. This is evidenced by the results of EC. High values of TDS in groundwater are generally not harmful to human beings, but high concentrations of these may affect people who are suffering from kidney and heart diseases [17]. Water containing high solids may cause laxative or constipative effects [20].

\section{Sulphate}

Spatial distribution of sulphate in the groundwater of the study area shows that the sulphate concentration varies between 40 and $114 \mathrm{mg} / \mathrm{l}$ (Fig. 5(g)). Higher sulphate concentrations of $114 \mathrm{mg} / \mathrm{l}$ were observed in areas like Injambakkam, Sholinganallur and Uthandi, whereas lower concentration were observed in Pallavaram and Selaiyur. Weathering of rocks due to rapid urbanization and industrialization, mixing of saline and fresh water, and the effluents from tanneries located in these regions may be reasons for the higher concentrations. From Fig. 4 it is evidenced that most of the study area is under the classification of settlements. Electrical conductivity of water is a direct function of its total dissolved salts [21]. Hence it is an index to represent the total concentration of soluble salts in water.

\section{Total Hardness}

Hardness is the important parameter for determining the usability of groundwater [22]. It is a measure of the capacity of water to the concentration of calcium and magnesium in water and is usually expressed as the equivalent of $\mathrm{CaCO}_{3}$ [23]. Total hardness is one of the most important properties of drinking water. Hardness may cause urolithiasis [24]. As per standards, the desirable value of $\mathrm{TH}$ for drinking water has to be within $300 \mathrm{mg} / \mathrm{l}$. In the study area it varies from 170 to $1,000 \mathrm{mg} / \mathrm{l}$. A higher TH concentration of $1,000 \mathrm{mg} / \mathrm{l}$ was observed in Madurapakkam due to cation exchange, whereas a lower concentration of 170 $\mathrm{mg} / \mathrm{l}$ was observed in Injambakkam and Sholinganallur (Fig. 5(h)). This is evidenced from the results of calcium and magnesium. Dissolved calcium and magnesium in water are the two most common minerals that make water hard.

\section{Bicarbonate}

Bicarbonate is a major element in our body. The most important effect of bicarbonate ingestion is the change in acid-base balance as well as blood $\mathrm{pH}$ and bicarbonate concentration in biological fluids. Bicarbonate also reduces the acidity of dietary components such as proteins. Bicarbonate has been shown to decrease dental plaque acidity induced by sucrose, and its buffering capacity is important to prevent dental cavities. Fig. 5(i) shows the spatial distribution of bicarbonate in the study area that varies from 110 to 668 $\mathrm{mg} / \mathrm{l}$. A higher concentration of $668 \mathrm{mg} / \mathrm{l}$ was observed in Pallavaram, whereas a lower concentration of $110 \mathrm{mg} / \mathrm{l}$ was observed in Injambakkam and Selaiyur. 
Table 2. WQI and status of water quality.

\begin{tabular}{|c|c|}
\hline WQI & Water quality status \\
\hline $0-25$ & Excellent \\
\hline $26-50$ & Good \\
\hline $51-75$ & Poor \\
\hline $76-100$ & Very poor \\
\hline$>100$ & Unfit for drinking \\
\hline
\end{tabular}

Source: Indian Drinking Water Standards and ICMR.

\section{Water Quality Index}

Table 2 shows the WQI and status of water quality as per Indian drinking water standards and ICMR standards. The weights of individual water quality parameters were calculated using Eq. (2) and the results are tabulated in Table 3. The WQI map with the weights shown in Table 3 is shown in Fig. 6.

The WQI of the study area varies from 81.096 to 142.561. From Fig. 6 it can be observed that water in areas like Pallikaranai, Madurapakkam, and Selaiyur are unfit for drinking, while water in areas like Sholinganallur, Uthandi, Pallavaram, Injambakkam, and Thiruneermalai have very poor WQI. This is due to the higher rate of pumping for the industrial and domestic needs. From the LULC map it is observed that the study area is experiencing fast urbanization due to the increase of industrial activities. Deposition

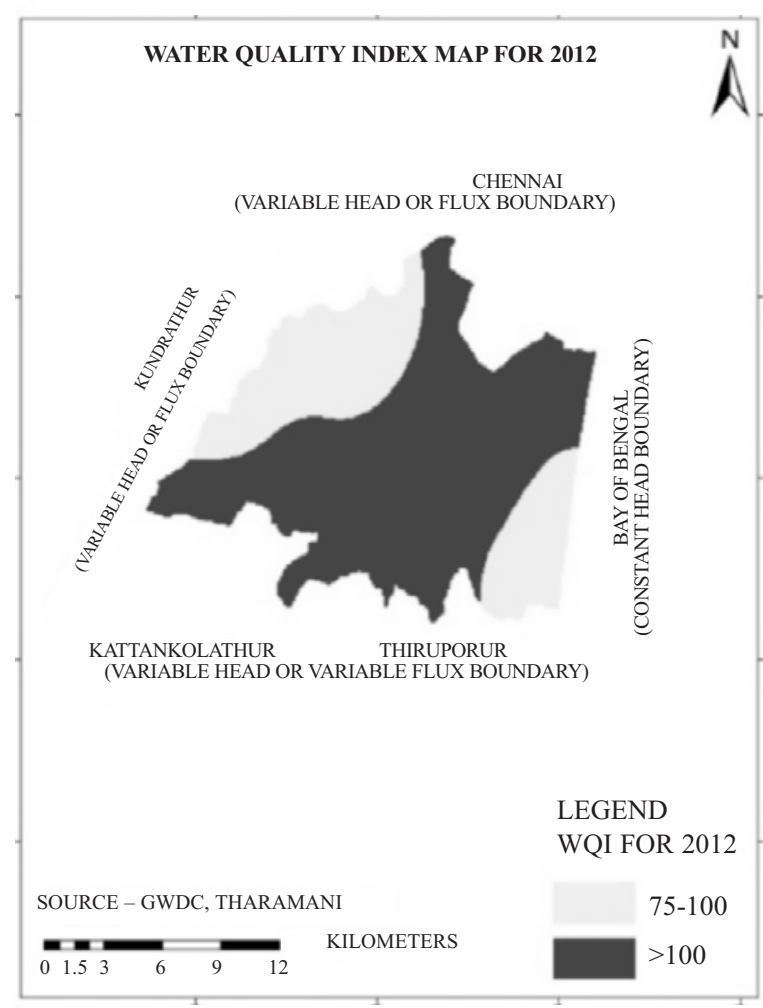

Fig. 6. Water quality index map.
Table 3. Water quality parameters, their ICMR/BIS standards, and assigned unit weights.

\begin{tabular}{|l|c|c|}
\hline \multicolumn{1}{|c|}{ Parameters } & Standards $\left(S_{n}\right.$ and $\left.S_{i}\right)$ & Weight $\left(W_{n}\right)$ \\
\hline $\mathrm{pH}$ & 8.5 & 0.629 \\
\hline Electrical conductivity & $300 / \Omega \mathrm{m}^{2}$ & 0.018 \\
\hline $\mathrm{TDS}$ & $500 \mathrm{mg} / \mathrm{l}$ & 0.011 \\
\hline $\mathrm{TH}$ & $300 \mathrm{mg} / \mathrm{l}$ & 0.018 \\
\hline Calcium & $75 \mathrm{mg} / \mathrm{l}$ & 0.071 \\
\hline Magnesium & $30 \mathrm{mg} / \mathrm{l}$ & 0.178 \\
\hline Chloride & $250 \mathrm{mg} / \mathrm{l}$ & 0.021 \\
\hline Sulphate & $200 \mathrm{mg} / \mathrm{l}$ & 0.027 \\
\hline Bicarbonate & $200 \mathrm{mg} / 1$ & 0.027 \\
\hline
\end{tabular}

of unauthorized wastes on the ground that leads to seepage of minerals into the ground and mixing of effluents with the surface water bodies is also one of the main reasons for very poor WQI.

\section{Conclusion}

The LULC maps of the study area for 2000 and 2012 were prepared and it was found that the agricultural land is reduced to $7.011 \%$, while the built-up area increased to $15.927 \%$, with the forest area remaining the same for both years, wasteland reduced to $3.645 \%$, water bodies decreased to $4.073 \%$, and wetlands reduced to $1.198 \%$. The spatial distribution maps for the drinking water quality parameters, such as $\mathrm{pH}, \mathrm{EC}, \mathrm{TDS}, \mathrm{TH}$, calcium, magnesium, bicarbonate, chloride, and sulphate were prepared. It was found that all the parameters exceed their limits due to rapid urbanization and industrialization and the unauthorized deposition of industrial wastes. WQI was calculated to determine the suitability of water for drinking purposes. Lack of rainfall, increase in pumping rate, lack of good water recharge structure, and encroachment of water catchment areas by built-up areas and industries were found to be the major causes for poor WQI. In areas like Pallikaranai, Madurapakkam, and Selaiyur water was found to be unfit for drinking while in areas like, Sholinganallur, Uthandi, Pallavaram, Injambakkam, and Thiruneermalai the WQI was very poor. Though the WQI in the study area improves during rainy season from poor to moderate, the water is not fit for drinking. To overcome this problem water recharge structures must be built in this block and the extraction of ground water has to be restricted.

\section{References}

1. PRASAD K. Institutional framework for regulating use of groundwater in India, Central Ground Water Board, Ministry of Water Resources, Government of India, 2008; http://cgwb.gov.in/INCGW/Kamta\%20Prasad\%20report.pdf, Accessed 28 September 2011. 
2. KUMAR C. P. Groundwater assessment methodology, National Institute of Hydrology, Roorkee, 2009; w.angelfire.com/nh/cpkumar/publication/Lgwa.pdf, Accessed August 2011.

3. KETATA MOUNA R., GUEDDARI M., BOUHLILA R. Use of geographical information system and water quality index to assess groundwater quality in El Khairat Deep Aquifer (Enfidha, Tunisian Sahel), Iranica J. Ener. Environ., 2, (2), 133, 2011.

4. YOGENDRA K., PUTTAIAH E. T. Determination of water quality index and suitability of urban water body in Shimoga Town, Karnataka. The $12^{\text {th }}$ World Lake Conference, 342346, 2008.

5. CHALLERJEE R., TARAFDER G., PAUL S. Groundwater quality assessment of Dhanbad district, Jharkhand, India. Bull. Eng. Geol. Environ., 69, (1), 137, 2009.

6. SHOMAR B., FAKHER S. A., YAHYA A. Assessment of groundwater quality in the Gaza Strip, Palestine using GIS mapping, J. Water Res. Protect., 2, 93, 2010.

7. ASADI S. S., VUPPAL P., REDDY A. M. Remote sensing and GIS techniques for evaluation of groundwater quality in municipal corporation of Hyderabad (Zone-V), India. Int. J. Environ. Res. Pub. Health, 4, (1), 45, 2007.

8. SENTHILNATHAN S., AZEEZ P. A. Influence of dyeing and bleaching industries on groundwater of Tirupur, Tamilnadu, India, Springer-Verlag, New York, 62, (3) 330, 2011.

9. World Health Organization (WHO), Guidelines for Drinking-Water Quality, $3^{\text {rd }}$ Edition, World Health Organization (WHO), Geneva, 2004.

10. PRADEEP J.K. Hydrogeology and Quality of Ground Water around Hirapur, District Sagar (M.P.), Pollution Research, 17, (1), 91, 1998.

11. NAEEM M., KHAN K., REHMAN S., JAVED I. Environmental Assessment of Ground Water Quality of Lahore Area, Punjab, Pakistan. J. Applied Sci. 7, 41, 2004.

12. AMBIGA K., DURAI A. Use of Geographical Information System and Water Quality Index to Assess Ground Water Quality in and around Ranipet Area, Vellore District, Tamilnadu. International Journal of Advanced Engineering Research and Studies, 73-80, 2013.

13. WHO (2005) Nutrients in Drinking Water. World Health Organization, Geneva, 186 (http://www.who.int/water sanitation health/dwq/nutrientsindw/en/index.html).
14. SRINIVAS RAO G., NAGESWARARAO G. Assessment of Groundwater quality using Water Quality Index, Arch. Environ Sci., 7, 1, 2013.

15. SONAWANE G. H., SHRIVASTAVA V. S. Ground Water Quality Assessment Nearer to the Dye user Industry. Archives of Applied Science Research 2, (6), 126, 2010.

16. REZA R., SINGH G. Assessment of Ground Water Quality Status by Using Water Quality Index Method in Orissa, India. World Applied Sciences Journal, 9, (12), 1392, 2010.

17. KHANAM Z., SINGH V. Groundwater Quality Assessment near Polluted Canal Area in Kichha Town, Uttarakhand, India. International Journal of Recent Scientific Research, 5, (2), 362, 2014.

18. OSIBANJO O., MAJOLAGBE A.O. Physicochemical Quality Assessment of Groundwater Based on Land Use in Lagos city, Southwest, Nigeria. Chemistry Journal, 2, (2), 79, 2012.

19. DEVI S., PREMKUMAR R. Physicochemical Analysis of Groundwater samples near Industrial Area, Cuddalore District, Tamilnadu, India. International Journal of ChemTech Research, 4, (1), 29, 2012.

20. SAWYER G N., CARTHY MC D. L. Chemistry of sanitary Engineers, $2^{\text {nd }}$ Ed., McGraw Hill, New York, 518, 1967.

21. RAMAKRISHNAIAH C.R., SADASHIVAIAH C., RANGANNA G. Assessment of Water Quality Index for the Groundwater in Tumkur Taluk, Karnataka State, India, EJournal of Chemistry, 6, (2), 523, 2009.

22. SHIVASHARANAPPA, SRINIVAS P., HUGGI M. S. Assessment of ground water quality characteristics and Water Quality Index (WQI) of Bidar city and its industrial area, Karnataka State, India. International Journal of Environmental Sciences, 2, (2), 965, 2011.

23. APHA Standard methods for the examination of water and waste water. American Public Health Association $21^{\text {st }}$ ed. Washington D.C, 2005.

24. CHARI K.V.R., LAVANYA M.G. Groundwater contamination in Cuddapah urban area, Andhra Pradesh. In Proceedings on regional Workshop of Environmental aspects of groundwater development. KU, Kurukshetra Oct. 17-19, Kurukshetra, India: 130-134, 1994. 
